\title{
Employee Motivation and its Effects on Employee Productivity/ Performance
}

\author{
${ }^{\mathrm{a}}$ Gifty Naa Boafoa Okine, ${ }^{\mathrm{b}}$ George Yaw Asare Addeh, ${ }^{\mathrm{b}}$ Babalola Emmanuel Olusola, ${ }^{\mathrm{c}}$ Isaac Asare \\ ${ }^{a}$ Methodist University College, Department of Business, Ghana \\ ${ }^{\mathrm{b}}$ Zhejiang Gongshang University, School of Public Administration, CN \\ ${ }^{\mathrm{c} S i c h u a n}$ Agricultural University, Agricultural Economics and Management Department. CN
}

\begin{abstract}
One of the most important functions of management is to ensure that employee work is more satisfying and to reconcile employee motivation with organizational goals. With the diversity of current jobs, this is a dynamic challenge. What people value and enjoy is influenced by many factors, including the influence of different cultural backgrounds. This research report examines employee motivation and its impact on employee performance. The study examines some common theories of motivation that can be used in an organization to improve employee performance. The study showed that employees have their differences in terms of the concept of motivation. Various forms of theories of motivation in literature have been debated along with their applications and implications. Three questions were examined: What is motivation? What kind of motivation can best be used to increase employee performance? The results of the study show that motivation can increase or decrease employee performance. If the chosen form of motivation meets the needs of the employee, their performance increases. If, on the other hand, the chosen form of motivation does not satisfy the needs of the employee, the benefit decreases. It therefore encourages organizations to understand the motivating need of each employee to improve performance.
\end{abstract}

Keywords: Motivations, Employee, Performance, Productivity

DOI: $10.7176 / \mathrm{JESD} / 12-16-11$

Publication date:August $31^{\text {st }} 2021$

\subsection{INTRODUCTION}

Thousands of years before arranging "motivation" was included in the live performance vocabulary, popular people knew the importance of influencing employees when performing tasks in the organization. One of the oldest technique, the use to inspire employees, known as the "carrot and whip" method. The name derives from the stubbornness of the councilors, it could control the roots that oversaw it. Over the years, good employee compensation has been one of the strategies that the company devises to improve the efficiency of the functions and thereby increase competing organizations. In addition, the current global economy tends to recognize most employers where employee performance is too sophisticated to measure an organization's success because of which companies he competed. On the other hand, he had the success of the employees in further business not only for the growth of organizations but also for the growth of the grandchildren employees. Employees only became amounts contributors to the company's production. If the study concludes that employees are not only active but also have important factors and affective variables in the company's production, ideas that employees he active alone may change. In addition, previous studies have shown that employees have not primarily driven by money, and at work he related to their behavior. For Joseph (2015), motivation is the most important factor in any organization. Motivation plays an important role in the success of any organization. All organizations face the problem of motivation, both in the public and in the private sector (Chintallo \& Mahadeo, 2013). According to Chaudhary and Sharma (2012), the term "reason" derives essentially from motivation. The meaning of "motive" is the needs and desires of the individual. "So" employee motivation means the mechanism by which our employees are motivated by the company in the form of incentives, promotional events, etc. to achieve organizational goals. Hislop (2003) defined motivation as a type of force that compels employees to do things that result from satisfying individual needs in order to be inspired to complete and continue the task.

What causes employees of any organization to "lose another mile" to deliver excellent service? Motivation is basically a combination of factors that affect each person and involves a combination of approaches. Motivation can generally be described as a blend of motivation and action. Aluko (2014) argues that an organization is only as successful as its workforce. This suggests that if employees are motivated, their morale will be high and the level of performance and efficiency will be significantly improved, increasing the overall level of performance of the organization. Therefore, managers must constantly look for ways to ensure that their employees continue to achieve high levels of productivity and also to improve the efficiency or productivity of the organization. 
Among other factors of production, human resources are the most important of all resources and human capital is what separates one company from another (Maimuna \& Rashad, 2013). Therefore, to be successful and remain relevant and competitive, companies must be able to hire and retain productive and efficient employees in an effort to increase productivity (Sunia, 2014). The overall success of an institution in achieving its strategic goals strongly depends on the degree of efficiency of the employees. Employee performance is a hallmark of skill and motivation, where skill consists of the skills, preparation and resources needed to perform a task and motivation is characterized as an inner strength that motivates people to act on something (Flippo , 2001.). He added that employee success in organizations translates into a more empowered workforce that requires greater efficiency, consistency, quantity, dedication and leadership. Employee motivation is therefore very necessary for organizations because physical, financial and human capital is required to achieve the goals of each concern. This can be achieved by improving the working capacity of employees. This will allow the company to make the best use of its resources. In this way, productivity improves, operating costs decreases and overall performance increases (Grant, 2008). When thinking about the production of a company, both must be traced back to the employees it inspires. In today's turbulent and sometimes unpredictable world, where business success depends on employees use of talent, motivation is indispensable (Joseph, 2015). An important aspect of a successful company is the ability to recruit, retain and grow talented employees. People are an organization's most important asset, especially in low-tech, labor-intensive industries like construction, but even then, people are often the most difficult asset for organizations to manage. Unlike material assets, if people are to contribute to the growth and development of an organization, they have their own individual needs that need to be met and behaviors that need to be controlled (Joseph, 2015). A company can have a good boss, a good vision and a good cause; but if it neglects its employees, the company is fundamentally in chaos.

\subsection{CONCEPT OF MOTIVATION}

\subsection{Motivation}

Motivation refers to the force that stimulates, controls and maintains behavior inside and outside the individual (Daft \& Noe, 2001). In Daft and Noah, a person's motivation affects arousal, energizes and sustains behavior, although these behaviors do not necessarily lead to reward or diminished behavior in the workplace. . According to (Anne \& Barry, 2005), motivation refers to the amount of effort a person puts in to do something. What does motivation mean? James and Stoner (2009) suggested that motivation can be seen as the psychological characteristics of a person that contribute to the determination to achieve a goal. It contains several elements that cause, control and maintain specific human behavior. He added that motivation is one of many components that influence the level of efficiency and effectiveness of the organization. Young (2000) also suggested that motivation can be specified in relation to the strength of employees in explaining levels, directions and solutions related to effort in the workplace. Berelson and Staines (2003) argue that motivation is an internal state that promotes goal-directed behavior as well as leadership and controlled action. Guay et al., (2010) argued that the reasons for behavior are related to motivation. Broussard and Garrison (2004) further described motivation simply as elements that force a person to act or not to act. Beach (2005) defined motivation as a person's willingness to expend energy to achieve set goals. Motivation is believed to refer to an individual's passion for specific tendencies or behaviors. He also stated that a person's goals, needs and desires can influence, control and regulate his attitude. Davies (2005) proposed that what goes on within a person that results in those actions is part of the principle of motivation. Eighth, Koontz (2008) argues that the motivation for the notion of man's necessity and desire is related.

According to Dubin (2002), motivation is a complex force in building and maintaining a person who enjoys being an organization. Motivation is more than talking to a person and coming up with reasons to get started. 'Personal motivation is a person who is motivated by a person who considers his motivation and ability to use his resources to achieve the goals of the organization. This is because it challenges the person into action and encourages the council to open a council. On the twentieth-century issue, the premiere of Latham and Ernest (2006), the motivation was just a newcomer. Medieval, opened in the 20th century. Rajput (2011) argues that the word motivator comes from the Latin word 'Movere', which literally means to impose a dispute. Therefore, the basic principle of motivational incentives for people who want to achieve different goals is because they take needs or expectations into account. The dynamic and changing nature of the introduction and purpose of employment implies a unique, consistent or two broad classifications of good motivation.

\subsubsection{Extrinsic Motivation}

To achieve better results and high employee productivity, there must be an effective external incentive system (Carraher, 2006). Although declared employee loyalty depends on remuneration and incentives for them. Social incentives help employees build trust to achieve company goals (Burke, 2002). Reio and Callahon (2004) 
suggest that employees are driven by external incentives and gain high productivity from them. It is an incentive to achieve a desired goal or other external reward, such as money or rewards (Walker et., 2006). External motivation, such as salary increases, awards, and promotions, is a way to fulfill indirect desires or something else offers as recognition of a job well done. According to Lin (2007), external motivation focuses on goal-driven factors, such as the incentives or rewards gained in completing a task. The combination of internal and external motivation influences individual motives and their real attitude to activity. To achieve a concrete result, external motivation can be described as performing an action (Ryan \& Deci, 2000). Externally oriented healthcare professionals are often involved in clinical practice from external motives such as incentives, positive feedback, recognition, etc., rather than from their own enjoyment of the task itself (inherent motivation). There are four forms of external motivation: integrated regulation, established regulation, internal regulation, and external regulation (Weinberg \& Gould, 2003). This view was supported by Shim et al., (2011) that external motivation is related to behavior that leads to activities that are not their own intentions, such as payments or compliments or dictations of others.

\subsubsection{Intrinsic Motivation}

Reio and Callahon (2004) argue that intrinsic incentives are used to inspire employees to be more productive. Lawler (2003) argues that the effectiveness of organizations depends on how motivated their employees are. In nature, the inner rewards are elusive. We can't touch them with our fingertips, but we can only feel them, such as gratitude, employer attitudes and job rotation. Internal rewards are rewards within the work itself, such as satisfaction with the performance of the task, the appreciation of the employer (Ajila, 2004). Because one has to feel competence and pride in something, an inner motivation can be created (McCullagh, 2005). Thus, internally motivated nurses perform health care activities with no apparent benefit other than the satisfaction and joy that comes with the job itself. Internal motifs come in three (3) forms (Weinberg \& Gould, 2003): awareness, success and relaxation. From birth, human beings are active, inquisitive and playful creatures in their healthiest state, with an omnipresent willingness to learn and explore, and without external stimuli to do so. Therefore, internal motivation is not the only form of motivation in humans or even voluntary behavior, but it is omnipresent and meaningful. While in one sense there is intrinsic motivation between individuals, in another sense there is intrinsic motivation in the relationship between individuals and activities. Because the connection between the individual and the task is intrinsic motivation, as some authors have defined intrinsic motivation in terms of an interesting task while others have defined it in terms of the satisfaction one receives from internally motivated involvement in the task. Furthermore, individuals are internally motivated for certain tasks and not others, and not everyone is internally motivated for a particular activity.

\subsection{Motivational Approaches}

Despite the variety of hypotheses researchers have tested, they have come to increasingly stress the importance of multiple motivational approaches to the success of employees. Motivation approaches have been described as tools and techniques which can be used to motivate employees and these are:

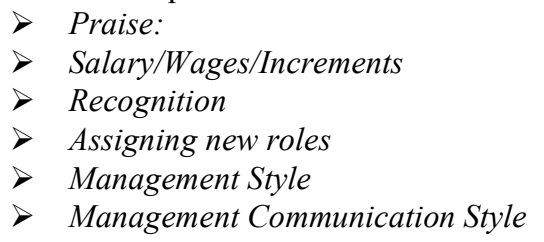

\subsection{Effect of Motivation on Employee Performance}

When dealing with clients, staff are the first calling point. Therefore, it is important for organizations to give employees the requisite motivation to inspire them to do more and achieve better organizational results. According to some researchers, encouragement raises the level of effectiveness in the workforce (Greeno, 2002) added that it is not just an employee's credentials, experiences, or skills that decide productivity but rather motivation plays a major role in deciding an employee's productivity. To fill the gap between an employee's skill and his willingness, the company must inspire the employee so that, according to his or her skills, he or she can give results. As companies boost employee performance through encouragement, it will also improve overall productivity, decrease costs, and increase the company's effectiveness. Barrit (2003) agreed with the statement by Greeno (2002) that motivation brings human capital into motion and increases the degree of employee performance. He added that to accomplish the objectives, every issue requires financial and human capital. Getting the staff only physically, does not mean that the company succeeds in making good use of it. Barrit (2003) added that the performance of motivated workers is high, resulting in improved efficiency and lower 
operating costs. He concluded that with little effort, a motivated employee will not struggle to get by, but will be more focused on his work. If those employees who spend much of their time on Facebook or other sites use their ability to keep themselves occupied with their job instead, improved productivity would be very visible (Barrit, 2003). Moreover, "an employee who is motivated by an enriching work will obtain a higher value than an employee not motivated" (Akerlof \& Kranton, 2005) and motivating employees will benefit both the employees as well as the business. Employees will have some of what they have for work and do the job with all their potential (Jen et al., 2004) And when businesses and organizations achieve quality improvement and good results from their workers, the incentive goes to the empowered staff (Chadwick et., 2004). said that high performance workers are generally able to give the company an extra effort when it is needed. Griffiths (2001) stressed that achieving personal targets helps an employee to remain motivated and to continue to deliver. He added that encouragement can make it easier for a worker to achieve his or her personal goals and can encourage an individual's self-development. Griffiths (2001) concluded that they understand the strong connection between effort and outcomes once the worker achieves some initial targets, which would further inspire them to continue at a high level. According to Attipoe, Wright Evans et al. (2021), performance reviews improve employee performance by helping them reach their full potential in fulfilling their company mission and by providing employees and managers with information that they can use to make business decisions. They also give employees feedback and are thus an engine for personal and professional development. However, performance evaluation presents problems due to its complexity.

Jesop (2005) stressed that encouragement brings staff closer to the business. He added that as long as employee needs are met by competitive incentives, promotional opportunities, etc., workers are beginning to take more interest in their company. They start believing that there is no distinction between the company's interests and their interests. This helps to create cordial relationships between management and employees. Zamer et. al., (2014) explain theoretically that motivation has significant function in public or private companies. Motivation is divided into two categories: monetary, such as income, incentives, salaries; and non-monetary, such as working conditions, employment status, job stability, job enrichment. While the performance of workers is classified into three dimensions, namely work efficiency, job quality, and job achievement. Research findings in the Pakistan beverage industry indicate that motivation plays a crucial role in employee success (Zamer et. al., 2014). Aworemi et al, based on. Research findings from a wide range of businesses (education, hotels, retail, manufacturing, services, and transportation) in Nigeria indicated that working conditions, interesting work and good pay are main factors for greater motivation of employees. Motivation has long been recognized as a very important factor for an organization because of the following advantages: putting human capital into action; enhancing employee efficiency; contributing to organizational goals; creating friendly relationships; leading to workforce stability; (Aworemi et. al., 2011). Motivation has, however, been taken for granted by many executives. Motivation, however, has been taken for granted by many executives. Based on his research findings in the cement manufacturing company in Nigeria, according to Dugguh (2014), it shows that low productivity occurs due to poor motivation of employees, and it implies that motivation is related to productivity because motivated employees are productive employees. This result confirms by Nwachukwu (2002), and earlier research on manufacturing firms, which requires encouragement and work satisfaction to increase productivity (Dugguh, 2014). Most researchers say, according to (Bradley, 2004), that there is an obvious connection between motivation and employee performance and they can deliver more if workers are motivated. Better results will also lead to good successes which will lead to greater encouragement. They have the ability to do the job needed honestly, as though workers are empowered and happy. Often, motivated workers do more work than others with their high ability as they are happy and having high results (Bradley, 2004). "If employees are motivated and happy, they will do to the work to the best of their ability instead of just doing it because they have to". (Ryan, \& Deci, 2000). Unmotivated workers, on the other hand, lose the enthusiasm in work that leads to quitting the job. Leaving seasoned staff hardly affects the job too much.

\section{Models of Employee Motivation}

Behavioral scientists and Psychologists have developed some motivation theories. There are a number of motivational theories which relates to employee performance. For the purpose of this study, the following theories will be discussed: Abraham Maslow Theory, McClelland's Motivational Theory (1971) and Frederick Herzberg's Two- Factor (Motivation-Hygiene).

\subsection{Maslow's Hierarchy of Needs Theory (1943)}

In his paper titled, "A Theory of Human Motivation," Abraham Maslow published a theory on what motivates human beings in 1943. In it, Maslow said that human beings had five levels of needs that they always sought to meet. The more fundamental the needs of life are, the more driven a person is to fulfill them. However, if they 
failed or were unable to fulfill them, they would feel more tension. The five stages of need are: physiological needs, needs for protection, needs for possession, needs for ego status and needs for self-actualization.

$\begin{array}{ll}> & \text { Physiological needs: } \\ > & \text { Health or Safety Needs: } \\ > & \text { Social Needs: } \\ > & \text { Needs of esteem: } \\ > & \text { Self-Actualization Need: }\end{array}$

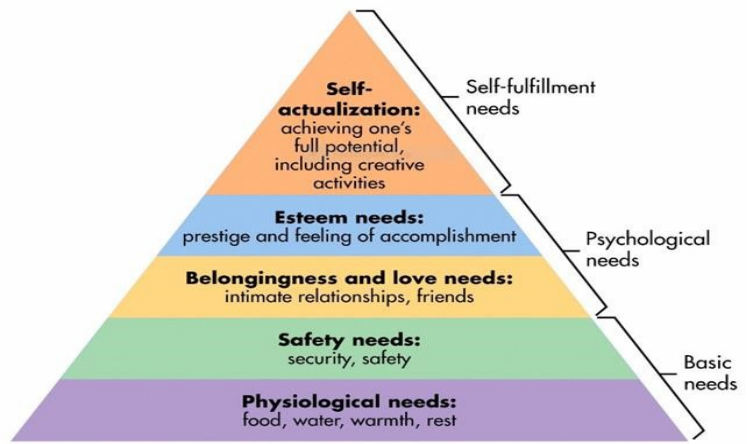

Figure 1: Maslow's Hierarchy of Needs Theory Source: (Anderson, 2014)

\subsection{McClelland's Motivational Theory}

The theory of David McClelland starts with the leadership group, and he "focuses on three significant needs that he thinks are culturally acquired and can therefore be changed by training." It does not deal with improvement and regression between needs, but with the needs/motives that have a big impact on work life efficiency and effectiveness. The needs of McClelland, which are also referred to as APA needs, include:

1. Achievement Needs: The challenge of success and the fear of failure are motivated by people in the third group. Also, their need for accomplishment is mild and they set for themselves moderately difficult tasks. They are analytical in nature and take calculated risks. This is the need for high performance to be accomplished and challenging and complex tasks to be mastered.

2. Power Needs: Basically, people for high need for power are inclined towards influence and control. They like to be at the center and are good orators. They are demanding in nature, forceful in manners and ambitious in life. They can be motivated to perform if they are given key positions or power positions. (Cole 2003). There is a desire to take responsibility, take control, gain influence, and make a difference gladly. McClelland distinguished between social power needs. The need to perform well for others and/or the entire company, and the requirements of personal influence, i.e. the need to produce personal benefit.

3. Need for affiliation: This is the need for social contact and the need for friendship to be formed and sustained. McClelland thought that all persons have different compositions of the three needs, but typically one of the three needs is dominated (Cole, 2003).

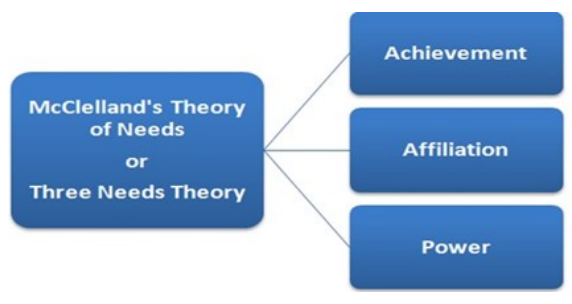

Figure 2: McClelland's Motivational Theory

\subsection{Frederick Herzberg's Two- Factor (Motivation-Hygiene) Theory}

After investigating the causes of job satisfaction and frustration among accountants and engineers, Herzberg et al. (1959) developed a two-factor model of satisfactory and dissatisfied. It has been assumed that people are given the opportunity to reliably report circumstances that have made them happy and dissatisfied with their 
work (Armstrong, 2010). Herzberg (2003) stated that intrinsic factors associated with job satisfaction are based on two types of motivators, i.e., factors that determine job satisfaction and factors that cause employee dissatisfaction at work, while external factors relate to dissatisfaction. Herzberg concluded from satisfactory performance that removing satisfactory performance from unsatisfactory work is satisfactory work (Armstrong, 2010). Herzberg defined two main variables: motivators of hygiene variables that can contribute to job satisfaction (Herzberg, 2003). Herzberg noted that motivators are intrinsic factors that encourage psychological growth and job creation, such as success, appreciation, responsibility, improvement, challenge, and work itself (Ajila \& Abiola, 2004). On the other hand, hygiene variables are external and working conditions are exactly the same (Armstrong, 2010). These include job security, salary, working conditions, company policy, management, supervision, relations between subordinates and supervisors (Bhattacharyya, 2009). Herzberg (2003) concludes that employees should not only worry about working conditions, but also about the job itself. According to Chris and Awonusi (2004), external incentives have a large effect on employee dependence, while internal rewards do not have a significant impact on employee impact.

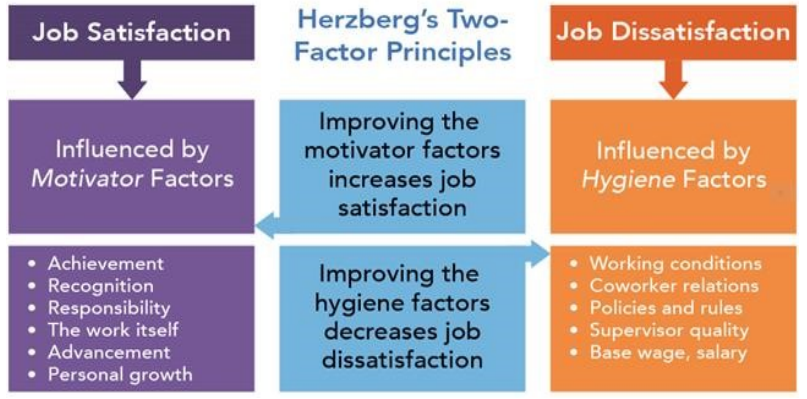

\section{Figure 1: Frederick Herzberg's Two- Factor (Motivation-Hygiene) Theory 4.0 DISCUSSION AND ANALYSIS}

This chapter discusses the implications of Maslow theory of Human needs, McClelland's Motivational Theory, Frederick Herzberg's Two- Factor (Motivation-Hygiene) Theory).

\subsection{Maslow's Hierarchy of Needs Theory}

If management wishes to improve the work satisfaction of employees, the essence of the job itself should be concerned with the opportunities it gives employees to acquire status, take responsibility, and achieve selfrealization. If management, on the other hand, aims to minimize dissatisfaction, then it must concentrate on policies, processes, supervision and working conditions in the work environment. Managers must pay attention to all sets of employment considerations in order to maintain a happy and efficient workforce.

Maslow theory of need is still very important and applicable in today's organizational environments. Despite its weaknesses, it has been able to identify those needs that are unique to an individual and the effects that they may have on the performance or productivity levels of an employee in an organization. Therefore, it is essential that managers strive to understand the needs that concern their staff members and provide sufficient encouragement designed to meet or fulfill those needs. The company must consider employees to be the core of the organization and an asset to the organization in order to attain high levels of efficiency. Maslow's theory therefore suggests that the needs of the workers must first be given due consideration to ensure that employees remain highly efficient and, in an attempt, to promote sustainable growth, prosperity and success of the company. Lawler (2003) in opposing the principle of needs claimed that his point was that the definition made some impractical assumptions concerning employees such as: (1) employees are identical (2) circumstances are equivalent and (3) there is an ultimate way of fulfilling needs. A joint view was also held by Basset-Jones and Lloyd (2004). While Maslow's theory was able to develop the fact that individuals have needs, it has failed to provide an appropriate correlation amongst specific need fulfillment and the realization of an establishment's goals and objectives. It also does not really provide remedies associated with the complications of motivational disparities in staff. Before recognizing self-actualized desires, his philosophy that lower needs be met was also not justified in other situations, as was seen in a few exceptions, though it might be valid in other cases. These involve people who were unable to cater to their deficiencies or lower needs, but were able to at least expose or satisfy those aspects of their needs for self-actualization. The happiness one gets after fulfilling each degree of need is very difficult to calculate, since it is subjective in nature because it deals with human minds that cannot be measured by any computer or system. Therefore, even after satisfying physiological and safety needs, some individuals will be satisfied, while some individuals will not be satisfied by meeting all levels of needs. 


\subsection{McClelland's Motivational Theory}

The main advantage of this theory is that company employees are assigned tasks according to their needs. There is no justification for why employees get a job based on their needs, and if a company also offers employees a job profile based on their interests, they should not blame the company for failing in the jobs assigned and in their jobs. Employees who give an excuse for not doing their job are eliminated because people give a job profile according to their needs. We have highly motivated employees to achieve the organization's goals. Particular emphasis is placed on mastery. They are motivated individuals who want to be recognized and praised for the task performed on their behalf. They prefer to work on tasks that seem difficult. The awards get feedback on your work. This is their motivation. Huge wages do not really affect them. Financial motivation may motivate them to some degree, but in a way, this category of employees becomes useless because there are no results for their name. What is the implication for you? Organizations are needed to identify such employees with this exceptional quality and challenge them as motivating. Risky, managers should not take risks by giving such employees and team assignments, but with individual assignments. Another form of motivation for models is the need to join or socialize. Some employees are highly motivated to enter into and maintain social relationships. They will feel loved, accepted and belong to the group. Employees with such an instinct will be highly motivated when placed in a group. Organizations can get the most out of these employees, not by increasing their salaries, but by creating an atmosphere of socialization. The main drawback of this theory is that this theory focuses on needs for achievement, power, and affiliation, but ignores essential needs such as food, shelter, and protection that are primary needs and must first be met before addressing other needs to be met. If one employee falls under the need for achievement matrix, he or she is likely to be stereotyped and will never work in the department where the need for power or association is needed, even if the worker has required qualification for the specific job.

\subsection{Frederick Herzberg's Two- Factor (Motivation-Hygiene) Theory}

To determine the impact of demographic factors on job satisfaction, Schroder (2008) used two-factor theory as the theoretical basis for a study of eight hundred and thirty-five university employees. The results of the research have largely shown that job satisfaction is related to age and academic success and that the degree of inherent and external job satisfaction varies for different work-related groups. Such conclusions contradict Herzberg's findings (Schroder, 2008). In addition, opponents of this theory argued that Herzberg's research assumed an established relationship between satisfaction and productivity, emphasizing greater satisfaction and neglecting productivity. Lin (2007) believed that job satisfaction is multivariate in nature, and the theory seeks to simplify a complex system of emotions and reactions between different variables with interrelationships. Stello (2011) also held that. An analysis of higher education staff in Uganda also found that any factor can cause job satisfaction or cause dissatisfaction with situational variables in the work environment (Sesanga \& Garrett, 2005). However, it is still very important for companies, despite criticisms of two-factor theory. This means that managers and their organizations must constantly ensure that hygiene factors are sufficient to prevent dissatisfaction among employees. This is because employee dissatisfaction contributes to a loss of morale, resulting in reduced employee productivity. Managers must also ensure that the type of work or tasks assigned to employees is demanding, fun, and satisfying to ensure that employees are motivated to increase the level of job-related performance. This concept emphasizes job enrichment to motivate employees to be extremely productive. Finally, to ensure that employees are highly efficient, supervisors must ensure that their skills and experience are maximized by the type of tasks assigned to employees. Focusing on motivation variables for both employees and the company as a whole will increase work quality and productivity.

\section{Summary and Conclusion}

Motivation affects the employee, motivation can have a negative impact on the employee or a positive impact depending on the employer's needs. From the literature, motivation is an important factor in determining employee satisfaction and performance. Employee motivation goes beyond financial rewards, which include both internal and external rewards. Organizations need to motivate employees individually, not as a group, because needs vary from employee to employee. The authors proposed a number of motivating strategies. The study examined Maslow's theory of needs, which includes the following: physiological needs, health needs, social needs, pricing of needs, and self-actualization. McClelland's theory of motivation. It consists of the need for success, the need for power and the need for belonging. The last form discussed is Frederick Herzberg's twofactor theory (motivation-hygiene). This includes motivational factors and hygienic factors. Each of these types of motivational strategies has its consequences when practiced. Therefore, managers must examine the needs of the employees before choosing which form or type to practice. In general, employee motivation tends to increase 
employee performance, as long as the motivation strategy adopted meets the needs of the employees. Organizations that always motivate their employees will enjoy greater productivity.

\section{References}

Anderson, A. (2014). Maslow's hierarchy of Needs. The Prairie Light Review, 36(2), pp. 7.

Armstrong, M., 2006, A Hand Book of Human Resource Management Practice, 7th edition, Kogan Page Limited London, U.K.

Armstrong, M. (2010). A Handbook of Human Resource Management Practice. 10th ed. Kogan Page: London.

Ajila, C., \& Abiola, A. (2004). Influence of Rewards on Workers Performance in an Organization. Journal of Social Science, 8(1), 7-12.

Assam, A. P. (2002). Motivation and job satisfaction. Unpublished Masters' Thesis, University of Lagos, Nigeria.

Attipoe, W.E., Agordzo, G.K., \& Seddoh, J. (2021). Effect of Performance Appraisal System on Employee Productivity;(Selected Public Senior High Schools, Ho Municipality, Ghana). Journal of economics and sustainable development, 12, 1-14.

Aluko, N. (November, 2014). 6 Challenges Facing Manufacturing Companies in Nigeria and Ghana. Kpakpakpa.com. Retrieved 13th January, 2017 from http://kpakpakpa.com/spotlight/challenges-facing-manufacturing-in-nigeria-ghana/

Akerlof, G. A., Kranton, R. E., (2005). "Identity and Economics of Organizations", Journal of Economic Perspectives, 19 (1), pp.9-32

Alderfer, C. P., 1969, an Empirical Test of a New Theory of Human Needs Organizational Behaviour and Human Performance, volume 4, issue 2, pp. 142-175.

Barrit, T. (2003). Management (6th ed). Houghton: Mifflin Company, Boston Accounting. Finance and Management Sciences. Vol. 4 No. 1 Jan 2014.

Aworemi, Abdul-Azeez, Durowoju (2011), an Empirical Study of the Motivational Factors of Employee in Nigeria. International Journal of Economics and Finance Vol. 3, No. 5.

Bradley, E. W., (2003). “Toward Understanding Task, Mission and Public Service Motivation: A Conceptual and Empirical Synthesis of Goal Theory and Public Service Motivation", Public Management Research Conference, Georgetown Public Policy Institute, pp. 9-11.

Basset-Jones, N. \& Lloyd, G. C. (2005), Does Herzberg's motivational theory have staying power? Journal of Management Development, 24(10), 57-56.

Berelson, B., \& Steiner, G. A. (2003) Human Behavior. New York, Brace and World.

Broussard, S. C., \& Garrison, M. E. B. (2004). The relationship between classroom motivation and Academic achievement in elementary school-aged children. Family and Consumer Sciences Research Journal, 33(2), 106-120.

Burke, W.W. (2002). Organizational Change: Theory and Practice. Sage: Thousand Oaks.

Beach D. S. (2005). Management of People at Work. London, Coller Macmillan.

Chadwick, C., Hunter, L. W., \& Walston, S. L. (2004). "Effects of downsizing practice on the performance of hospitals", Strategic management Journal, 25(5), pp. 405-427.

Chris, A., \& Awonusi, A. (2004). Influence of Rewards on Workers Performance in an Organization. Journal of Social Science, 8(1), 7-12.

Carraher, R, Gibson, A. \& Buckley R (2006). Compensation in the Baltic and the USA, Baltic Journal of Management Vol. 1, pp 7-23.

Cole, G.A., 2003, Management Theory and Practice, 4th Ed. ELBS, DP Publications, ISBN 185805060 X.

Chintalloo, S \& Mahadeo, J. (2013). Effect of Motivation on Employees’ Work Performance at Ireland Blyth Limited: Proceedings of 8th Annual London Business Research Conference Imperial College, London, UK, 8 ISBN: 978-1-922069-28-3.

Chaudhary, N \& Sharma, B. (2012). Impact of Employee Motivation on Performance (Productivity) In Private Organization: International Journal of Business Trends and Technology, volume2, Issue 4.

Deci, E. L., (1971). "Effects of externally medicated rewards on intrinsic motivation”, Journal of Personality and social Psychology, 18 (1), pp. 105-115 
Dugguh, S, I. (2014). Using motivation theories to enhance productivity in cement manufacturing Companies in Nigeria: An overview. The International Journal of Social Sciences. 28th Feb 2014. Vol. 20, No. 1.

Davies, J. (2005). Review of effects of task factors on job attitude and job behavior II. Job Enlargement and Organizational Context, Perdonsi Psychology 22, $41-426$.

Dubrin AJ (2004). Leadership: Research findings, Practice and Skills, Houghton Mifflin Company, New York ISBN: 0-618-30596-3.

Dick, C., (2003). "Linking employee satisfaction with productivity, performance and customer satisfaction", Group leader of financial services.

Esanga, K. \& Garrett, R. (2005). Job satisfaction of university academics: Perspectives from Uganda. Higher Education, 50(1), 33-56.

Greeno, S. (2002). Human capital management: achieving added value through people. Kogan: Pager limited.

Guay, F., Chanal, J., Ratelle, C. F., Marsh, H. W., Larose, S., \& Boivin, M. (2010). Intrinsic, identified, and Controlled types of motivation for school subjects in young elementary school children. British Journal of Educational Psychology, 80(4), 711-735.

Grant, A. M., 2008, The significance of task significance: Job Performance effects, relational Mechanisms, and boundary conditions, Journal of Applied Psychology, 93, 108-124 Flippo E., 2001, Personnel management, New York: Mc Graw Hill.

Herzberg, F., Mausner, B., \& Snyderman, B.B. (1959). The motivation to work. N.Y.: Wiley \& Sons.

Herzberg, F. (2003). One more time: how do motivate employees? Harvard Business Review, 81, 86-96.

Hislop, D., (2003). "Linking human resource management and knowledge management via commitment: A Review and research agenda", Employee Relations, 25(2), pp. 182-202.

Jen, H., Chyan, Y., Bih-Huang, J., and Hero, C., (2004). "Measuring satisfaction with business to employee Systems", Computer in Human Behavior, 20, pp. 17-35.

Jesop, T. (2005). Improving employee's performance through human resource management. London: Hoffman press.

Joseph, O. B. (2015). The effect of employees' motivation on organizational. Journal of Public Administration And Policy Research, 7(4), 63-66.

James A. F, Stoner, R. F. (2009). Management. Patarang, Delhi, India: Dorling Kindersley.

Koontz, O.D. (2008). The Social Psychology of Industry. Penguin Books.

Latham GP, Ernst CT (2006). Keys to motivating tomorrow's workforce. Human Resource Management Review, 16, 181-198.

Lin, H. F. (2007). Effects of Extrinsic and Intrinsic Motivation on Employee Knowledge Sharing Intentions. Journal of Information Science.

Lawler, E. E. (2003). Reward practices and performance management 52 system effectiveness. Center for Effective Organizations.

Lin, H. F. (2007). Effects of extrinsic and intrinsic motivation on employee knowledge sharing intentions. Journal of Information Science, 33(2), 135-149.

Maimuna, M. N., \& Rashad, Y. F. (2013). The impact of employee training and development on employee Productivity. Global Journal of Commerce and Management Perspective, 2(6), 91-93.

Maslow, A. H. (1943). A Theory of Human Motivation. Psychological Review, 50(4), 370-96Maslow, A. (1943). A theory of human motivation. New York: Harper \& Row.

Mani, V., 2010. Development of Employee Satisfaction index scorecard, European Journal of Social Sciences, 15(1): 129-132.

Ryan, R. M., \& Deci, E. L. (2000). Self-determination Theory and Facilitation of Intrinsic Motivation, Social Development, and Well-Being. American Psychologist, 55(1), 68.

Reiss, S., 2004, Desires”, Review of General Psychology, 8 (3): 179-193.

Reio, G, T. \& Callahon, J. L. (2004). Affect, Curiosity, and socialization-related Learning; a path analysis of Antecedents to job performance, Journal of Business and Psychology, Vol.19, pp3-22.

Rajput, A., Bakar, A. H. A., and Ahmad, M. S., 2011, "Motivators Used by Foreign and Local Banks in Pakistan, a Comparative Analysis”, Journal of Academic Research, Vol. 3, No. 2. 
Stello, C. M. (2011). Herzberg's two satisfaction: An integrative literature review. Paper presented at the 2011 Student Research Conference: Exploring Opportunities in Research, Policy, and Practice, University of Minnesota Department of Organizational Leadership, Policy and Development, Minneapolis.

Sunia, F. (2014). Factors that predict employee retention in profit and not-for-profit Organizations. Global Journal of Human Resource Management 2(4), 1-8.

Shim, J. P., \& Ahn, K. M. (2011). Social networking service: Motivation, pleasure, and behavioral intention to use. Journal of Computer Information Systems, 51(4), 92-101.

Schroder, R. (2008). Job satisfaction of employee at a Christian university. Journal of Research on Christian Education 17(2), 225-246

Walker, C. O., Greene, B. A., \& Mansell, R. A. (2006). Identification with Academics, Intrinsic/Extrinsic Motivation, and Self-efficacy as Predictors of Cognitive Engagement. Learning and Individual Differences, 16(1), 1-12.

Weinberg, R. S., \& Gould, D. (2003). Introduction to psychological skills training. Foundations of sport and Exercise Psychology.

Zameer, Hashim; Ali, Shehzad; Nisar, Waqar \& Amir, Muhammad (2014). The impact of the motivation on the Employee's Performance In Beverage Industry of Pakistan. 